\title{
Managerial Ownership and Intellectual Capital Efficiency: Evidence From Poland
}

\author{
Leszek Bohdanowicz \\ University of Lodz, Lodz, Poland
}

\begin{abstract}
This article contributes to the corporate governance and intellectual capital literature and examines the relationship between managerial ownership and intellectual capital efficiency (ICE). The results were obtained by investigating a sample of 1,057 firm-year observations and 292 companies listed on the Warsaw stock exchange between 2008 and 2013. Since the data span covers six years, panel data analysis (fixed-effects model) is employed. The empirical analysis indicates that managerial ownership is negatively related to human capital efficiency (HCE), which is partly consistent with some previous studies. As such, it indicates the entrenchment effect of insider ownership. Moreover, the study concludes that these and previous results on the relationship between managerial ownership and IC efficiency are not robust due to ICE measures, which now are employed in research.
\end{abstract}

Keywords: corporate governance, managerial ownership, intellectual capital, Poland

\section{Introduction}

Interest in intellectual capital and intangible assets has been increasing in recent years, because its creation and efficiency are seen as an important source of competitive advantage (Hamel \& Prahalad, 1990). Therefore, some authors underlined that companies oriented on intellectual capital will be winners in terms of future value (Lin \& Edvinsson, 2008). In view of this, intellectual capital has also become a subject of some researches, which examined the relationship among its risk, value or efficiency and company performance (Firer \& Williams, 2003; Riahi-Belkaoui, 2003), corporate value (Tseng \& Goo, 2005), knowledge performance (Wiig, 1997), types of innovative capabilities (Subramaniam \& Youndt, 2005), disclosure practices (Williams, 2001), business strategy (Joia, 2000), business start-up success (Peña, 2002), organizational culture (Sánchez-Cañizares, Muñoz, \& López-Guzmán, 2007), board structure (Swartz \& Firer, 2003), and some others (Bohdanowicz \& Urbanek, 2013).

In a nutshell, many studies on intellectual capital showed that there is a need for further research, which will explain the conditions conducive to the creation and use of intellectual capital. This study refers also to this problem and is held in the Polish system of corporate governance. Since this system is two-tier one, i.e. corporate boards consist of supervisory boards and management boards, ownership is concentrated and one of the most influential owners is the insider; the main aim of this study is to examine how in these circumstances

Leszek Bohdanowicz, Ph.D. in Business Economics, Department of Finance and Strategic Management, Faculty of Management, University of Lodz, Lodz, Poland.

Correspondence concerning this article should be addressed to Leszek Bohdanowicz, Department of Finance and Strategic Management, Faculty of Management, University of Lodz, Matejki Street 22/26, 90-237 Lodz, Poland. E-mail: lbohdan@uni.lodz.pl. 
managerial ownership affects the ICE. As such, this study tries to fill the gap in the literature. To put it briefly, there have been little studies on the relationship between ownership structures and intellectual capital (Celenza \& Rossi, 2013). This study refers to the association between managerial ownership and ICE measured by the value added intellectual coefficient (VAIC) and explain the relationship between them on the basis of agency theory.

The reminder of the paper is organized as follows. In Section 1 the related literature is reviewed and the hypothesis is developed. Section 2 describes the sample selection and the variables. Section 3 provides descriptive statistics and empirical results on the relation between managerial ownership and ICE. Finally, conclusions, including research limitations, are presented.

\section{Literature Review}

\section{Agency Theory and Managerial Ownership}

Agency theory is based on the separation of ownership and control (the agency problem) and it describes the situation, in which the interests of shareholders (principals) and managers (agents) are divergent (Jensen \& Meckling, 1976). Both parties, i.e. the principals and agents, seek to maximize their utility. The owners' objective is to increase the value of their shares. The managers tend to increase their remuneration including perks, and are not always acting in accordance with the expectations of their principals, unless they have shares and thus their interests are aligned with shareholders' interests. In some modern companies, especially in Anglo-Saxon countries, ownership is dispersed and single shareholders do not have enough incentives to control agents, who in reality control the companies' assets. Some studies indicated that concentrated ownership in the hands of individual shareholders increases their tendency to monitor managers and motivate them to achieve the owners' objectives more conscientiously (Jensen \& Warner, 1988). Therefore, ownership concentration and managerial ownership are considered as the most effective mechanisms of corporate governance (La Porta, Lopez-de-Silanes, \& Shleifer, 1998).

But in contrast, in some countries, ownership is concentrated (Becht \& Röell, 1999). This creates the principal-principal problem (conflict between majority shareholders and minority shareholders), as the largest controlling shareholders enjoy private benefits of control (Faccio \& Lang, 2002; Renders \& Gaeremynck, 2012). However, the presence of majority shareholders can diminish the conflicts of interest between the owners and managers, because shareholders are exposed to greater risk by investing in company shares. Their investments are usually long-term, and, in contrast to the minority shareholders, they cannot "vote with their feet" and have a stronger incentive to actively monitor the managers (La Porta et al., 1998; Renders \& Gaeremynck, 2012).

The agency problem changes its nature when ownership is concentrated and in addition the key owners are top managers. Morck, Shleifer, and Vishny (1988) mentioned that manager who controls a substantial fraction of the firm's equity may have enough voting power or influence more generally to guarantee his employment with the firm at an attractive salary. Moreover, owner-managers can dominate corporate boards, entrench themselves, and reduce the role of the external directors or the supervisory board members in two-tier board model (Bohdanowicz, 2014; Short \& Keasey, 1999; Mace, 1972).

\section{Managerial Ownership and Firm Performance}

Previous studies on the relationship between managerial ownership and company performance gave mixed results. On one hand, there are studies, which underlined that the relationship between them is non-monotonic 
(Demsetz \& Villalonga, 2001). On the other hand, there are researches, which emphasized that there exist the significant and positive connections between them (Jelinek \& Stuerke, 2009). In addition, other studies found the piecewise-linear relationship between managerial ownership and firm performance (Morck et al., 1988).

Among the studies, which highlighted the non-monotonic nature of the relationship between managerial ownership and company performance, there is a lack of compliance at intervals, changing the nature of this relationship, for example, Morck et al. (1988) noted an increasing relation between $1 \%$ and 5\%, a decreasing one between $5 \%$ and $25 \%$, and an increasing one beyond 25\%. But Vintila and Gherghina (2012) noticed a positive relationship until a threshold of $35.58 \%$ and a negative relationship beyond the threshold. Moreover, Cheng, Su, and Zhu (2012) examined a sample of Hong Kong listed companies and found that managerial ownership has an "entrenchment-alignment-entrenchment" effect on company performance. Due to this, managerial ownership positively affects the companies' performance at a wide medium ownership range from $22.18 \%$ to $78.02 \%$. But in opposition, at very low and very high levels of managerial ownership, examined impact is negative.

Moreover, previous studies tried to find the association between the fraction of executives' equities and both accounting, e.g. ROA (Jelinek \& Stuerke, 2009) and market measures of companies' performance, e.g. Tobin's Q (Chen, Guo, \& Mande, 2003). Also the results of research on the association between managerial ownership and both types of measures were mixed, for example, Warrad, Almahamid, Slihat, and Alnimer (2013) investigated the relationship between managerial ownership and company performance measured by accounting and market measures in Jordanian non-financial listed companies and they found that managerial ownership do not have a significant effect on ROA and ROE, but substantial fraction of equities in hands of managers has a significant effect on Tobin's Q.

These results show that the relationship between managerial ownership and company performance can be highly dependent on measures and generally on the system of corporate governance, in which the study was conducted. But for now, most of researches have supported the view that this relationship is non-monotonic.

\section{Ownership and Intellectual Capital}

There were some researches on the relationship among managerial ownership or ownership concentration, company performance and ICE (Celenza \& Rossi, 2013; Tsai, Yu, \& Wen, 2013). Some of these researches concerned the relationship between ICE and managerial ownership (Bohdanowicz \& Urbanek, 2013; Saleh, Rahman, \& Hassan, 2009), but as Celenza and Rossi (2013) stated, especially the association between intellectual capital and ownership structure was little examined.

However, Saleh et al. (2009) investigated 264 companies listed on the MESDAQ market of Bursa Malaysia and found only the weak and negative relationship between managerial ownership and the VAIC, but in opposition to their expectation, managerial ownership was not related to its components. They concluded that these results lead them to question the competency of the Malaysian managers in creating value given the existing resources, but it should be the subject of future research.

Different variables on intellectual capital are used studies of Tsai et al. (2013). They investigated companies listed on the Taiwan stock exchange between 2004 and 2008. To measure intellectual capital, they employed the ratio of spending on human resources divided by sales, R\&D intensity, and advertising intensity. But they were concentrated rather on the association between company performance and intellectual capital, than on the association between ownership structure and intellectual capital. They did not find any relationship between company performance and measures of intellectual capital in their whole sample. 
Bohdanowicz and Urbanek (2013) utilized the sample of the Polish companies listed on the Warsaw stock exchange between 2006 and 2011. Amongst others, they found a negative relationship between VAIC and ownership by management board members. Moreover, ownership by management board members was negatively related to structural capital efficiency (SCE).

Finally, Celenza and Rossi (2013) investigated the association between ownership concentration and ICE in 43 Italian companies. They mentioned that the relationship between ICE and ownership concentration is frequently positive, but not significant.

Overall, based on agency theory, the above discussion and despite the ambiguous previous results, the hypothesis can be posed that managerial ownership has a positive influence on ICE.

\section{Research Method}

\section{Sample}

The sample consists of Polish companies listed on the Warsaw stock exchange between 2008 and 2013. Data was hand-collected and derived from annual reports or supervisory boards annual statements. The sample concentrates only on non-financial companies. Financial institutions are excluded due to their unique financial structure and special accounting rules for financial sectors. Following Firer and Williams (2003) in this study, companies with negative book value of equity or negative structural capital and at the same time negative value added (VA) are eliminated. Moreover, observations with missing data are also excluded. This gives an unbalanced panel initial sample of 292 companies and 1,057 firm-year observations.

\section{Variables}

The following model is used for testing the hypothesis:

$$
Y_{i t}=\alpha_{i}+\beta X_{i t}+\gamma Z_{i t}+\varepsilon_{i t}
$$

where, the $Y_{i t}$ vector contains the dependent variables, i.e., ICE measured by the value-added intellectual coefficient (model 1), the HCE (model 2), the SCE (model 3), the capital employed efficiency (CEE) (model 4), or the ICE (model 5); the $X_{i t}$ vector includes independent variable, i.e., managerial ownership; the $Z_{i t}$ vector consists of the control variables, specifically supervisory board diversity, supervisory board size, frequency of supervisory board meetings, management board diversity, management board size, company size, and leverage; the $\varepsilon_{\mathrm{it}}$ describes random disturbance.

Since the data span covers six years, panel data analysis (fixed-effects model) is employed.

In this study, ICE, which is a dependent variable, is measured by value-added intellectual coefficient $\left(\right.$ VAIC $\left.^{\mathrm{TM}}\right)$. This proxy variable was used by Pulic (2000), Firer and Williams (2003), and Nazari and Herremans (2007). VAIC is a financial valuation method and uses accounting data. It contains not only the efficiency of intellectual capital, but also the efficiency of employed capital. For this reason, the ICE is examined as a separate coefficient. However, capital employed comprises physical and financial capital. To calculate VAIC, it is necessary to count initially its three components i.e. HCE, SCE, and CEE. All of them are calculated as efficiency rates using VA measurement. The general VAIC formula takes the form:

$$
\mathrm{VAIC}^{\mathrm{TM}}=\mathrm{HCE}+\mathrm{SCE}+\mathrm{CEE}
$$

The different efficiency rates and the VA rate are calculated using the following formulas:

$$
\begin{aligned}
\mathrm{HCE} & =\mathrm{VA} / \mathrm{HC} \\
\mathrm{SCE} & =\mathrm{SC} / \mathrm{VA}
\end{aligned}
$$




$$
\begin{gathered}
\mathrm{CEE}=\mathrm{VA} / \mathrm{CE} \\
\mathrm{ICE}=\mathrm{HCE}+\mathrm{SCE} \\
\mathrm{VA}=\mathrm{OP}+\mathrm{HC}+\mathrm{D}+\mathrm{A}
\end{gathered}
$$

where, HC stands for labour costs (salaries and employee benefits), SC stands for amount of structural capital, $(\mathrm{SC}=\mathrm{VA}-\mathrm{HC}), \mathrm{CE}$ stands for book value of net assets, OP stands for operational profit, and $\mathrm{D}+\mathrm{A}$ stands for depreciation and appreciation.

Managerial ownership is the percentage of shares owned by all the management board members (Bohdanowicz, 2014). This variable is calculated as direct and indirect voting rights at the general meeting and counted as a decimal number.

Then, there are employed five board variables. The Polish board model is two-tier one and corporate boards in Poland consist of two separate bodies, that is supervisor boards and management boards. Supervisory boards are composed of only external directors and fulfill control and eventually advisory function. Management boards are composed of only internal directors and are responsible for management of companies' operations and their strategies. Anyway, since the Polish board model is two-tier, in this study, there are employed three supervisory board variables and two management board variables, which control their roles in companies. Supervisory board variables are supervisory board size, supervisory board diversity, and frequency of supervisory board meetings. Management board variables are management board size and management board diversity. As a proxy for diversity, gender diversity is used, which is measured as the percentage of women on the supervisory board and separately on the management board (Campbell \& Minguez-Vera, 2008). This variable is counted as a decimal number. Board size is calculated as the total number of directors (Yermack, 1996). As a proxy for supervisory board activity, the number of meetings held by the supervisory board is used (Brick \& Chidambaran, 2010; Vafeas, 1999).

Moreover, as a proxy for the scale of the company (company size), total assets at the end of the company's prior fiscal year are used (lnTA). As it is commonly done, this is transformed with a natural logarithm (Kang, Cheng, \& Gray, 2003). Furthermore, debt ratio is used to control company leverage (LEVER). This is calculated as the ratio of total liabilities to total assets (Crespí-Cladera \& Gispert, 2003).

\section{Results}

\section{Descriptive Statistics}

Table 1 shows the descriptive statistics and correlation matrix for the variables considered. The mean VAIC across the entire sample is 2.8925, which is similar to this received by Bohdanowicz and Urbanek (2013), but higher than the VAIC in the study of Saleh et al. (2009), where it was 2.063. The mean of HCE is lower and amounts to 2.1127, as compared to 2.221 in the study by Saleh et al. (2009). Furthermore, the mean of SCE is higher than in the compared study, where it was 0.202 , and in this study it counts 0.3338 . CEE is also higher and here it counts 0.5342 against 0.043 in the quoted study. Moreover, the mean of ICE is 2.2539 in this study, which is slightly higher than in the study by Saleh et al. (2009), where it was 2.019. These differences may result from a different structure of the sample as well as from the time of observation.

Managerial ownership in the sample is relatively high. The mean is 0.2163 and standard deviation is 0.2745. This mean is higher than reported, for example by Ozkan (2007) for British companies, but lower than reported by Greco (2010) for Italian companies. Generally, these results indicate that large fraction of listed companies' shares belongs to the management boards' members. 
Table 1

Descriptive Statistics and Correlation Matrix

\begin{tabular}{|c|c|c|c|c|c|c|c|c|}
\hline & Mean & S.D. & 1. & 2. & 3. & 4. & 5. & 6. \\
\hline VAIC & 2.8925 & 1.9332 & 1.00 & & & & & \\
\hline HCE & 2.1127 & 2.1554 & 0.93 & 1.00 & & & & \\
\hline SCE & 0.3338 & 0.5535 & 0.62 & 0.39 & 1.00 & & & \\
\hline CEE & 1.1301 & 0,5089 & 0.13 & -0.15 & -0.02 & 1.00 & & \\
\hline ICE & 2.2539 & 1.5395 & 0.95 & 0.95 & 0.71 & -0.12 & 1.00 & \\
\hline MANOWN & 0.2163 & 0.2745 & -0.11 & -0.13 & -0.04 & 0.03 & -0.10 & 1.00 \\
\hline SBSIZE & 5.7386 & 1.3013 & 0.14 & 0.14 & 0.12 & -0.04 & 0.18 & -0.28 \\
\hline SBDIV & 0.1339 & 0.1686 & -0.05 & -0.05 & 0.00 & -0.03 & -0.06 & 0.25 \\
\hline SBFREQ & 6.3491 & 3.3052 & -0.03 & -0.04 & 0.03 & -0.02 & -0.03 & -0.22 \\
\hline MBSIZE & 3.0618 & 1.4483 & 0.07 & 0.04 & 0.09 & 0.01 & 0.09 & -0.03 \\
\hline MBDIV & 0.1126 & 0.2168 & 0.07 & 0.09 & -0.03 & 0.00 & -0.06 & 0.06 \\
\hline LNTA & 19.4681 & 1.6704 & 0.22 & 0.23 & 0.23 & -0.13 & 0.31 & -0.25 \\
\hline \multirow[t]{2}{*}{ LEVER } & 0.4748 & 0.2573 & -0.05 & -0.11 & -0.05 & 0.25 & -0.05 & 0.05 \\
\hline & 7. & 8. & 9. & 10 & & 11. & 12. & 13. \\
\hline 7. SBDIV & 1.00 & & & & & & & \\
\hline 8. SBDIV & -0.05 & 1.00 & & & & & & \\
\hline 9. SBFREQ & 0.18 & 0.11 & 1.00 & & & & & \\
\hline 10. MBSIZE & 0.33 & -0.06 & 0.11 & 1.00 & & & & \\
\hline 11. MBDIV & -0.13 & -0.07 & -0.01 & -0.09 & & 1.00 & & \\
\hline 12. LNTA & 0.55 & -0.06 & 0.30 & 0.53 & & -0.10 & 1.00 & \\
\hline 13. LEVER & 0.01 & 0.07 & 0.02 & 0.09 & & 0.00 & 0.08 & 1.00 \\
\hline
\end{tabular}

Notes. MANOWN: managerial ownership; SBSIZE: supervisory board size; SBDIV: supervisory board diversity; SBFREQ: frequency of supervisory board meetings; MBSIZE: management board variables; MBDIV: management board diversity.

Moreover, the mean of supervisory board size in the sample is 5.7386, which shows that some supervisory boards count only the minimum number of members, which in Poland for listed companies is five members. The average of management board size is 3.0618 with standard deviation 1.4483. According to the Polish company law, the minimum for management boards is one member.

Supervisory board diversity is 0.1339 with standard deviation 0.1686 . It means that approximately $14 \%$ of board members are female directors. To compare, management board diversity is even lower and amounts 0.1126 with standard deviation 0.2168 . These results indicate the dominance of both Polish boards by male directors and low gender diversity in the Polish boardrooms.

The average supervisory board meeting frequency across the entire sample is 6.3491 with standard deviation 3.3052. It is similar to the average obtained by Bohdanowicz (2014) in the Polish listed companies, but slightly lower than observed by Vafeas (1999), where there were 7.45 meetings, and Greco (2010), where there were 9.27 meetings in one-tier board model. Generally, the number of boards of directors in one-tier board model seems to be higher than the number of supervisory board meetings in two-tier board model.

The average debt ratio is 0.4748 with standard deviation 0.2573 and the mean natural logarithm of total assets (company size) is 19.4681 with standard deviation 1.6704 .

\section{Regression Analysis}

Table 2 illustrates the results of the panel data estimation for the sample. It shows that managerial 
ownership, which is independent variable, has a negative and significant impact on $\operatorname{HCE}(\beta=-1.1585, p<0.01)$. This result stands in opposition to the prediction. Moreover, there is no significant association between managerial ownership and other dependent variables, i.e. value-added intellectual coefficient, SCE, and CEE. Overall, these results do not support hypothesis.

Table 2

Panel Data Estimation of the Ownership Structures and Intellectual Capital Efficiency

\begin{tabular}{|c|c|c|c|c|c|}
\hline \multirow{2}{*}{$\begin{array}{l}\text { Independent and control } \\
\text { variables }\end{array}$} & \multicolumn{5}{|c|}{ Dependent variables } \\
\hline & $\begin{array}{l}\text { Model 1 } \\
\text { VAIC }^{\mathrm{TM}}\end{array}$ & $\begin{array}{l}\text { Model } 2 \\
\text { HCE }\end{array}$ & $\begin{array}{l}\text { Model } 3 \\
\text { SCE }\end{array}$ & $\begin{array}{l}\text { Model } 4 \\
\text { CEE }\end{array}$ & $\begin{array}{l}\text { Model } 5 \\
\text { ICE }\end{array}$ \\
\hline \multirow{2}{*}{ MANOWN } & -0.0801 & $-1.1585^{* *}$ & -0.0541 & 0.0684 & -0.1923 \\
\hline & $(0.4002)$ & $(0.4446)$ & $(0.1711)$ & 0.1165 & $(0.3445)$ \\
\hline \multirow{2}{*}{ SBDIV } & -0.1484 & 0.3407 & 0.1266 & $-0.2425 \dagger$ & 0.0423 \\
\hline & $(0.4767)$ & $(0.5363)$ & $(0.2066)$ & 0.1404 & $(0.4100)$ \\
\hline \multirow{2}{*}{ SBSIZE } & $-0.2021 *$ & $-0.2217^{*}$ & -0.0416 & $-0.0530 *$ & -0.1362 \\
\hline & $(0.078934)$ & $(0.0887)$ & $(0.0342)$ & 0.0233 & $(0.0681)$ \\
\hline \multirow{2}{*}{ SBFREQ } & -0.0029 & -0.0262 & -0.0017 & -0.0058 & -0.0047 \\
\hline & $(0.0217)$ & $(0.0243)$ & $(0.0094)$ & 0.0063 & $(0.0187)$ \\
\hline \multirow{2}{*}{ MBDIV } & -0.0031 & -0.2006 & 0.0306 & 0.0300 & -0.0541 \\
\hline & $(0.3485)$ & $(0.38812)$ & $(0.1496)$ & 0.1017 & $(0.2997)$ \\
\hline \multirow{2}{*}{ MBSIZE } & -0.1036 & -0.0193 & -0.0440 & 0.0063 & $-0.1403 *$ \\
\hline & $(0.0674)$ & $(0.0759)$ & $(0.0292)$ & 0.0199 & $(0.0582)$ \\
\hline \multirow{2}{*}{ Ln TA } & $0.5147 * *$ & $0.5524 * *$ & $0.3505^{* * *}$ & $-0.1403 *$ & $0.6920 * * *$ \\
\hline & $(0.1848)$ & $(0.2076)$ & $(0.0800)$ & 0.0544 & $(0.1591)$ \\
\hline \multirow{2}{*}{ Leverage } & $-0.9007 * *$ & $-1.1323^{*}$ & $-0.5646^{* *}$ & 0.5389 & $-1.3775^{* * *}$ \\
\hline & $(0.4043)$ & $(0.4532)$ & $(0.1752)$ & 0.1187 & $(0.3482)$ \\
\hline \multirow{2}{*}{ Constant } & -5.1966 & -6.4177 & $-5.8695 * * *$ & $3.9556 * * *$ & $-9.3194 * *$ \\
\hline & $(3.5540)$ & $(3.9945)$ & $(1.5385)$ & 1.0470 & $(3.0591)$ \\
\hline$N$ & 1,051 & 1,056 & 1,056 & 1,057 & 1,045 \\
\hline Adjusted $R$-squared & 0.6800 & 0.7649 & 0.2664 & 0.9997 & 0.6265 \\
\hline
\end{tabular}

Note: $\dagger p<0.1 ; * p<0.05 ; * * p<0.01 ; * * * p<0.001$; standard error is given in brackets; MANOWN: managerial ownership; SBSIZE: supervisory board size; SBDIV: supervisory board diversity; SBFREQ: frequency of supervisory board meetings; MBSIZE: management board variables; MBDIV: management board diversity.

There is also some relationship between the control variables and dependent variables. Supervisory board diversity is negatively related to $\operatorname{CEE}(\beta=-0.2425, p<0.1)$, but is not related to other dependent variables. Moreover, supervisor board size is also negatively related to $\operatorname{CEE}(\beta=-0.0530, p<0.05)$, but in addition negatively related to value-added intellectual coefficient $(\beta=-0.2021, p<0.05)$ and $\operatorname{HCE}(\beta=-0.2017, \mathrm{p}<$ $0.05)$. These results support the view that supervisory boards are passive in Poland and have little influence on company performance (Bohdanowicz, 2014; Jeżak, 2010). Furthermore, management board size is negatively related to $\operatorname{ICE}(\beta=-0.1403, p<0.05)$.

Moreover, there is a positive relationship between company size (natural logarithm of total assets) and four of dependent variables, i.e. value-added intellectual coefficient $(\beta=0.5147, p<0.01)$, $\operatorname{HCE}(\beta=0.5524, p$ $<0.01)$, SCE $(\beta=0.3505, p<0.001)$, and ICE $(\beta=0.6920, p<0.001)$, but negative relationship between company size CEE $(\beta=-0.1403, p<0.05)$. However, it indicates that larger companies better utilize intellectual capital. 
Furthermore, leverage is negatively associated with value-added intellectual coefficient $(\beta=-0.9007, p<$ $0.01)$, HCE $(\beta=-1.1323, p<0.05)$, SCE $(\beta=-0.5646, p<0.05)$, and ICE $(\beta=-1.3775, p<0.001)$. It reveals that debt negatively affects ICE.

\section{Conclusions}

The main aim of this study is to examine how managerial ownership affects the ICE, which has been measured by the VAIC and its components, specifically HCE, SCE, CEE, and in addition ICE. The conducted analysis has given only support to the negative relationship between managerial ownership and HCE. Moreover, this relationship seems to be monotonic, since attempts to find non-monotonic relationship have failed (not included). However, this research gives further evidence that insider ownership is negatively related to VAIC or its components (Saleh et al., 2009; Bohdanowicz \& Urbanek, 2013). As such, this study has found that managerial ownership is rather characterized by entrenchment effect, but not by alignment effect, which is also consistent with some previous studies on the relationship between insider ownership and firm performance, so that it identified at substantial fraction of the firm's equity owned by top managers (Morck et al., 1988).

Furthermore, this research has been conducted in two-tier board and it has been possible to identify the relationship between supervisory board or management board characteristics and ICE. This research has revealed that supervisory board size and management board size are negatively related to VAIC or its components, specifically supervisory board size to value-added intellectual coefficient, HCE, and CEE, but management board size to ICE. This relationship is consistent with corporate governance literature on board size and findings that large corporate boards are ineffective in monitoring (Eisenberg, Sundgren, \& Wells, 1998; Yermack, 1996). Moreover, there has been found the weak negative relationship between supervisory board diversity and CEE. It stands opposition to some researches on significant of gender diversity (Campbell \& Minguez-Vera, 2008), but supports other studies, which give contradictory conclusions (Ahern \& Dittmar, 2012).

The results of this study are also subject to limitations associated with the measurement of variables, which can affect the results and make them unclear. It concerns the dependent variable. Although the value-added intellectual coefficient is easy to calculate and is based on audited financial data which allows its use for intercompany comparisons (Firer \& Williams, 2003), it has a number of drawbacks that limit its use as a fully objective measure (Andriessen, 2004; P. Stahle, S. Stahle, \& Aho, 2011). However, its simplicity and the fact that calculations are based on readily available and comparable data make the value-added intellectual coefficient a proxy variable frequently used in studies on ICE (Chen, Cheng, \& Hwang, 2005; Firer \& Williams, 2003). But more in-depth conclusions can be drawn in the future, when new methods will be found that were removed through the VAIC's weaknesses.

\section{References}

Ahern, K. R., \& Dittmar, A. (2012). The changing of the boards: The impact on firm valuation of mandated female board representation. Quarterly Journal of Economics, 127(1), 137-197.

Andriessen, D. (2004). Making sense of intellectual capital, designing a method for the valuation of intangibles. Oxford: Elsevier Butterworth-Heinemann.

Becht, M., \& Röell, A. (1999). Blockholdings in Europe: An international comparison. European Economic Review, 43(4-6), 1049-1056.

Bohdanowicz, L. (2014). Managerial ownership and supervisory board activity: Evidence from Polish listed companies. Organizaciju vadyba: sisteminiai tyrimai (Management of Organizations: Systematic Research), 70, 41-54. 
Bohdanowicz, L., \& Urbanek, G. (2013). The impact of ownership structure on intellectual capital efficiency: Evidence from Polish emerging market. Retrieved from http://ssrn.com/abstract=2372412

Brick, I. E., \& Chidambaran, N. K. (2010). Board meetings, committee structure, and firm value. Journal of Corporate Finance, 16, 533-553.

Campbell, K., \& Minguez-Vera, A. (2008). Gender diversity in the boardroom and firm financial performance. Journal of Business Ethics, 83(3), 435-451.

Celenza, D., \& Rossi, F. (2013). Ownership concentration, intellectual capital, and firm performance: Evidence from Italy. China-USA Business Review, 12(12), 1157-1174.

Chen, C. R., Guo, W., \& Mande, V. (2003). Managerial ownership and firm valuation: Evidence from Japanese firms. Pacific-Basin Finance Journal, 11, 267-283.

Chen, M. Ch., Cheng, S. J., \& Hwang, Y. (2005). An empirical investigation of the relationship between intellectual capital and firms' market value and financial performance. Journal of Intellectual Capital, 6(2), 159-176.

Cheng, P., Su, L., \& Zhu, X. (2012). Managerial ownership, board monitoring and firm performance in a family-concentrated corporate environment. Accounting and Finance, 52, 1061-1081.

Crespí-Cladera, R., \& Gispert, C. (2003). Total board compensation, governance and performance of Spanish listed companies. Labour, 17(1), 103-126.

Demsetz, H., \& Villalonga, B. (2001). Ownership structure and corporate performance. Journal of Corporate Finance, 7 , 209-233.

Eisenberg, T, Sundgren, S., \& Wells, M. T. (1998). Larger board size and decreasing firm value in small firms. Journal of Financial Economics, 48, 35-54.

Faccio, M., \& Lang, L. (2002). The ultimate ownership of Western European corporations. Journal of Financial Economics, 65(3), 365-395.

Firer, S., \& Williams, S. M. (2003). Intellectual capital and traditional measures of corporate performance. Journal of Intellectual Capital, 4(3), 348-360.

Greco, G. (2010). Determinants of board and audit committee meeting frequency. Managerial Auditing Journal, 26(3), $208-229$.

Hamel, G., \& Prahalad, C. K. (1990). The core competence of the corporation. Harvard Business Review, 68(3), 79-91.

Jelinek, K., \& Stuerke, P. (2009). The nonlinear relation between agency costs and managerial equity ownership: Evidence of decreasing benefits of increasing ownership. International Journal of Managerial Finance, 5(2), 156-178.

Jensen, M. C., \& Meckling, W. H. (1976). Theory of the firm: Managerial behavior, agency cost and ownership structure. Journal of Financial Economics, 3(4), 305-360.

Jensen, M., \& Warner, J. B. (1988). The distribution of power among corporate managers, shareholders, and directors. Journal of Financial Economics, 20, 3-24.

Jeżak, J. (2010). Ład korporacyjny: Doświadczenia światowe oraz kierunki rozwoju. Warszawa: C.H. Beck.

Joia, L. A. (2000). Measuring intangible corporate assets: Linking business strategy with intellectual capital. Journal of Intellectual Capital, 1(1), 68-84.

Kang, H., Cheng, M., \& Gray, S. J. (2007). Corporate governance and board composition: Diversity and independence of Australian boards. Corporate Governance: An International Review, 15(2), 194-207.

La Porta, R., Lopez-de-Silanes, F., \& Shleifer, A. (1998). Corporate ownership around the world (NBER Working Papers 6625, National Bureau of Economic Research).

Lin, C. Y. Y., \& Edvinsson, L. (2008). National intellectual capital: Comparison of the Nordic countries. Journal of Intellectual Capital, 9(4), 525-545.

Mace, M. L. (1971). Directors: Myth and reality. Boston: Harvard Business School Press.

Morck, R., Shleifer, A., \& Vishny, R. W. (1988). Management ownership and market valuation: An empirical analysis. Journal of Financial Economics, 20, 293-315.

Nazari, J. A., \& Herremans, I. M. (2007). Extended VAIC model: Measuring intellectual capital components. Journal of Intellectual Capital, 8(4), 595-609.

Ozkan, N. (2007). Do corporate governance mechanisms influence CEO compensation? An empirical investigation of UK companies. Journal of Multinational Financial Management, 17, 349-364.

Peña, I. (2002). Intellectual capital and business start-up success. Journal of Intellectual Capital, 3(2), 180-198.

Pulic, A. (2000). VAIC ${ }^{\mathrm{TM}}$ —An accounting tool for IC management. International Journal of Technology Management, 20(5-8), $702-714$. 
Renders, A., \& Gaeremynck, A. (2012). Corporate governance, principal-principal agency conflicts, and firm value in European listed companies. Corporate Governance: An International Review, 20(2), 125-143.

Riahi-Belkaoui, A. (2003). Intellectual capital and firm performance of US multinational firms: A study of the resource-based and stakeholder views. Journal of Intellectual Capital, 4(2), 215-226.

Saleh, N. M., Rahman, M. R. Ch. A., \& Hassan, M. S. (2009). Ownership structure and intellectual capital performance in Malaysia. Asian Academy of Management Journal of Accounting and Finance, 5(1), 1-29.

Sánchez-Cañizares, S. M., Muñoz, M. Á. A., \& López-Guzmán, T. (2007). Organizational culture and intellectual capital: A new model. Journal of Intellectual Capital, 8(3), 409-430.

Short, H., \& Keasey, K. (1999). Managerial ownership and the performance of firms: Evidence from the UK. Journal of Corporate Finance, 5(1), 79-101.

Stahle, P., Stahle, S., \& Aho, S. (2011). Value added intellectual coefficient (VAIC): A critical analysis. Journal of Intellectual Capital, 12(4), 531-551.

Subramaniam, M., \& Youndt, M. A. (2005). The influence of intellectual capital on the types of innovative capabilities. Academy of Management Journal, 48(3), 450-463.

Swartz, N. P., \& Firer, S. (2005). Board structure and intellectual capital performance in South Africa. Meditari Accountancy Research, 13(2), 145-166.

Tsai, J. H., Yu, J., \& Wen, S. Y. (2013). Intellectual capital, corporate governance, and firm performance. Information Management and Business Review, 5(10), 482-491.

Tseng, Ch. Y., \& Goo, Y. J. J. (2005). Intellectual capital and corporate value in an emerging economy: Empirical study of Taiwanese manufacturers. $R \& D$ Management, 35(2), 187-201.

Vafeas, N. (1999). Board meeting frequency and firm performance. Journal of Financial Economics, 53, 113-142.

Vintila, G., \& Gherghina, S. C. (2012). An empirical investigation of the relationship between corporate governance mechanisms, CEO characteristics and listed companies performance. International Business Research, 5(1), 175-191.

Warrad, L., Almahamid, S. M., Slihat, N., \& Alnimer, M. (2013). The relationship between ownership concentration and company performance: A case of Jordanian non-financial listed companies. Interdisciplinary Journal of Contemporary Research in Business, 4(9), 17-39.

Wiig, K. M. (1997). Integrating intellectual capital and knowledge management. Long Range Planning, 30(3), $399-405$.

Williams, S. M. (2001). Is intellectual capital performance and disclosure practices related? Journal of Intellectual Capital, 2(3), 192-203.

Yermack, D. (1996). Higher market valuation of companies with a small board of directors. Journal of Financial Economics, 40, 185-211. 